\title{
EKSISTENSI PERANGKAT PEMBELAJARAN DALAM MENINGKATKAN AKTIVITAS DAN PRESTASI BELAJAR SISWA
}

\author{
Oktaviandi Bertua Pardede ${ }^{1}$, Diana Lestari Br. Sitompul ${ }^{2}$, Sri Melati Pertiwi Pinem ${ }^{3}$, \\ Sry Putrika $S^{4}$.
}

Email: Oktaviandibertuapardede@unprimdn.ac.id ${ }^{1}$, dianalestari21457@gmail.com ${ }^{2}$, pinemsrimelati@gmail.com 2, Sryputrikas@gmail.com ${ }^{3}$.

Program Studi Pendidikan Bahasa Indonesia, Fakultas Keguruan dan Ilmu Pendidikan

Universitas Prima Indonesia

\begin{abstract}
Abstrak
Upaya dalam menerapkan Eksistensi belajar siswa yang diisntrumentalkan tes yang digunakan dalam melakukan penelitian yang memiliki tujuan untuk mengetahui prestasi belajar siswa terhadap materi yang diberikan oleh guru. Analisis bahan ajar yang digunakan harus relavan sesuai dengan kurikulum yang disusun, pertanyaan atau soal yang di berikan sesuai dengan materi yang sudah di ajarkan kepada siswa, penerapan soal yang disusun dengan uji coba 20 butir soal pilihan berganda diketahui dari hasil tes bahwa 50\% siswa nilainya dibawah 50 dan nilai tertinggi hanya dapat dicapai $5 \%$ siswa atau satu orang saja yang mendapat nilai dikelas tersebut. Hasil ini menunjukkan bahwa belajar dikelas ini masih rendah, dengan Kriteria Ketuntasan Minimal (KKM) Bahasa Indonesia yang digunakan oleh (guru) adalah 70, berdasarkan hasil tes ini dapat diketahui bahwa 19 siswa yang tidak mencapai KKM, dan hanya 1 siswa saja yang dapat mencapai nilai tersebut. Dari hasil uji coba angket yang dijabarkan melalui beberapa indikator dirincikan menjadi 20 bulir-bulir pertanyaan, dengan 5 pilihan jawaban ordinal ( sangat setuju, ragu-ragu, tidak setuju, dan sangat tidak setuju), dapat diketahui bahwa 90\% siswa bersemangat mengikuti pelajaran Bahasa Indonesia yang menggunakan perangkat pembelajaran. Hal ini menggambarkan bahwa aktivitas belajar siswa akan semakin kondusif jika (guru) mengajar sesuai dengan (perangkat pembelajaran), dari hasil angket juga menunjukkan 39\% siswa yang merasa tegang dan takut selama mengikuti aktivitas yang dilakukan oleh guru. Sebagian 20 indikator angket juga terdapat 2 kriteria yang persentasinya kurang dari 50\% dan 17 kriteria lainnya lebih dari 60\% dari data yang tertera, aktivitas belajar siswa semakin optimal dengan adanya pengajaran yang disusun dengan perangkat pembelajaran, dari hasil angket dapat disimpulkan bahwa nilai yang diberikan terhadap penggunaan perangkat pembelajaran dalam mengajar adalah 74,4. Pelaksanaan observasi yang telah dilakukan selama 3 bulan berkenaan dengan keobjektivitasan terhadap sekolah dan integrasi dengan tujuan tertentu dapat diketahui bahwa 90\% siswa tampak bersemangat mengerjakan tes dan setiap aktivitas belajar yang disusun oleh guru, namun pada interaksi belajar dan inisiatif terdapat 50\% siswa yang menunjukkan perilaku yang sesuai dengan tujuan peneliti. Ditambah lagi $60 \%$ siswa yang pernah mengikuti lomba atau kreaktivitas sekolah antar pelajar, dengan hasil ini dapat diketahui bahwa aktivitas belajar siswa dan prestasi masing-masing menunjukkan adanya ketidak seimbangan walaupun guru sudah mengoptimalkan fungsi perangkat pembelajaran dalam proses pengajarannya.
\end{abstract}

Kata kunci : Eksistensi, Perangkat Pembelajaran, dan Aktivitas Siswa. 


\section{A. PENDAhuluan}

Dalam mewujudkan pembelajaran yang sesuai dengan tujuan pendidikan merupakan tugas utama pendidik sebagai agen pembaharuan. Melalui lembaga pendidikan yaitu sekolah, pendidik ditekankan untuk mampu mengoptimalkan setiap aspek yang dituju dalam pendidikan. Tentu aspek yang dimaksud adalah seluruh komponen pembelajaran yang berkaitan dengan peserta didik. Sehingga bagi pendidik, kompetensi dalam mengelola pembelajaran sangat diperlukan guna mengoptimalkan pencapaian tujuan pendidikan.

Jika diperhatikan secara komprehensif, ternyata tujuan pendidikan hanya terwujud jika objek yang dibelajarkan mengalami peningkatan kemampuan dan keterampilan. Peserta didik sebagai objek utama pembelajaran menjadi indikator terpenting dalam pencapaian tersebut. Hal ini juga dapat dipahami sebagai tolak ukur pendidik untuk memahami kesiapannya dalam mengajar. Oleh sebab itu, setiap pendidik dituntut untuk mampu merencanakan dan mengelola pembelajaran secara terukur dan realistis.

Secara nyata kecenderungan yang berkaitan dengan perencanaan dan pengelolaan pembelajaran di sekolah mengarah pada perangkat pembelajaran kelas. Penyusunan dan penggunaan perangkat tersebut memberikan wujud mekanisme yang utuh kepada guru selama melaksankan tugasnya. Oleh sebab itu, hal ini sepenuhnya merupakan hak dan kewajiban guru dalam mengemban kinerja profesinya. Sehingga kompetensi guru akan lebih optimal dengan adanya perangkat pembelajaran itu. Hal ini diperkuat ketika peneliti mewawancarai ibu Sahida Yanti S.Pd. yaitu guru di SMP Daya Cipta Medan yang merupakan objek penelitian ini. Secara terperinci narasumber menjelaskan bahwa perangkat pembelajaran yang dikembangkan oleh guru masih konvensional yaitu guru masih lebih aktif dalam proses belajar siswa. Ditambah lagi kinerja guru kurang dimonitoring oleh pihak sekolah, artinya guru masih cenderung melakukan sistem pengajaran yang tidak professional selama di sekolah. Hasil wawancara juga menunjukkan bahwa aktivitas belajar siswa juga belum aktif, masih cenderung siswa belajar dari buku pegangan tanpa ada instruksi tambahan lainnya. Siswa juga hanya mendengar dan memperhatikan guru selama mengajar di kelas.

Hasil wawancara di atas menggambarkan bahwa guru belum mengoptimalkan perangkat pembelajaran dalam pembelajaran. Tampak juga guru masih mengutamakan metode pembelajaran yang masih konvensioal, sehingga siswa hanya menguasai pembelajaran dari buku pegangan saja tanpa ada perlakuan pembelajaran yang berbeda pada setiap materi pelajaran bahasa Indonesia. Berdasarkan wawancara juga diketahui bahwa ketidakaktifan siswa selama belajar dipengaruhi oleh minimnya pemahaman guru tentang fungsi perangkat 
pembelajaran. Oleh sebab itu, perlu diketahui keberadaan perangkat pembelajaran dalam profesiguru.

Pengetahuan tentang keberadaan perangkat pembelajaran diasumsikan penting untuk diketahui secara eksplisit. Peneliti meyakini terdapat kemungkinan bahwa perangkat pembelajaran yang difungsikan oleh guru berkaitan dengan aktivitas dan prestasi belajar siswa. Hal ini perlu diketahui oleh peneliti karena sebagai seorang calon pendidik merasa perlu mengantisipasi dan menghadapi dinamika pembelajaran di masa yang akan datang. Sebagai calon guru bahasa Indonesia, variabel penelitian ini sangat melekat dengan kinerja guru di sekolah. Oleh sebab itu, keberadaan perangkat pembelajaran akan dianalisis secara objektif melalui aktivitas belajar dan prestasi siswa. Prestasi belajar siswa akan terpengaruh dengan perangkat yang di berikan oleh pendidik dalam mengembangkan prestasi belajar pada siswa tersebut, guru memberikan media sebagai alat untuk mengembangkan psikomotorik pada siswa. Kemudian agar siswa mampu mengikuti perkembangan tersebut diperlukan bimbingan dari seorang pendidik Syaiful S. B. (2008).

Selanjutnya defenisi pembelajaran sebagai rangkaian kegiatan yang berkaitan dengan beragam proses interaksi peserta didik dan sumber belajar pada lingkungan belajar, yang meliputi guru dan siswa, kurikulum, sarana dan prasarana pendidikan lainnya akan menjadi fokus penelitian ini. Guru sebagai salah satu komponen yang memengaruhi proses pembelajaran, secara operasional dituntut untuk mampu memperhatikan berbagai komponen dalam sistem pembelajaran yang meliputi: menyusun rencana pembelajaran, menyiapkan materi yang relevan, merancang metode yang disesauikan dengan situasi dan kondisi siswa, menyediakan sumber dan media belajar (Aqib Zainal, 2002: 22). Perangkat pembelajaran yang merupakan komponen yang dipersiapkan oleh guru sebelum memulai proses pembelajaran harus disusun dan dimuat selaras dengan tujuan yang dibelajarkan. Secara umum perangkat pembelajaran dapat berupa perlengkapan dan alat media di kelas (papan tulis, proyektor/infocus), silabus, Rencana Pelaksanaan Pembelajaran (RPP), bahan ajar (handout), media powerpoint dan komponen pendukung belajar lainnya. Oleh Sebab itu, tolak ukur terciptanya aktivitas belajar yang optimal dan prestasi belajar siswa yang berkompeten sangat ditentukan oleh keberadaan perangkat belajar yang dikembangkan oleh guru bersama sekolah.

Sehubungan itu, maka guru bahasa Indonesia pada penelitian ini akan berkewajiban menggunakan perangkat pembelajaran sesuai dengan dasar keilmuan bahasa, dan selanjutnya akan dikelola menjadi bahan dasar mekanisme mengajar guru di kelas. Sehingga dengan perangkat pembelajaran yang lengkap dan sistematis akan membantu guru mewujudkan 
pembelajaran yang interaktif, inspiratif, menyenangkan, menantang, serta memotivasi siswa untuk berpartisipasi secara aktif, kreativitas, dan memiliki kemandirian sesuai dengan bakat, minat, dan perkembangan fisik serta psikologi siswa (Depdiknas, 2007). Eksistensi pembelajaran penelitian ini berfokus pada fungsi dan manfaatnya selama guru melaksanakan tugas dan tanggungjawabnya di kelas maupun di sekolah. Oleh sebab itu tolak ukur eksistensi pembelajaran dalam penelitian ini akan menguraikan dan meninjau komponen pembelajaran secara komprehensif. Jadi untuk mengetahui eksistensi perangkat pembelajaran maka setiap komponen pembelajaran yang mencakup aktivitas belajar dan prestasi siswa akan dijadikan acuan pengukurannya.

Pencapaian prestasi siswa sangat dipengaruhi oleh aktivitas belajar yang didesain guru sebagai tenaga profesional. Hal ini dikuatkan oleh Pardede, O.B. (2019: 8) bahwa, "Profesi guru (pendidik) merupakan satu-satunya bidang pekerjaan yang membutuhkan beragam keterampilan dan kemampuan berupa hard skill dan soft skill”. Sehingga pada prosesnya, penggunaan Rencana Pelaksanaan Pembelajaran (RPP), silabus, media pembelajaran dan cakupan komponen lainnya yang termuat pada kurikulum harus mampu dikembangkan, dioptimalkan dan diimprovisasi oleh guru secara professional. Komponen lainnya juga, seperti pengelolaan sumber belajar, tata ruang kelas dan sarana/ prasarana sekolah serta sistem pendidikan yang dianut oleh sekolah juga perlu dipahami keterkaitannya terhadap keberadaan perangkat pembelajaran. Jadi, kecenderungan tercapainya prestasi dan aktivitas belajar siswa sangat berkaitan dengan keberadaan perangkat pembelajaran tersebut.

Selanjutnya aktivitas belajar siswa yang dilakukan di dalam lingkungan sekolah maupun di luar sekolah aktivitas meliputi fisik atau mental. Pada penelitian ini aktivitas pembelajaran diorientasikan pada aktivita siswa di kelas VIII SMP Daya Cipta Medan. Peneliti akan menyesuaikan indikator aktivitas pembelajaran dengan perangkat pembelajaran/ RPP yang disusun oleh guru di sekolah itu. Aktivitas belajar juga akan diamati secara langsung oleh peneliti dan dinilai keaktifannya melalui instrument yang akan dikembangkan.

Pada akhirnya eksistensi perangkat pembelajaran ini sangat berkaitan dengan keilmuan bahasa Indonesia, yaitu keterampilan berbahasa guru sangat mendukung konsistensinya dalam mengoptimalkan setiap materi pelajaran bahasa Indonesia melalui perangkat pembelajaran baik secara lisan maupun tulisan. Perangkat ini juga berperan dalam bahasa Indonesia sebagai indikator pencapaian pelajaran bahasa Indonesia melalui program yang dikelola oleh sekolah serta dapat membantu para peserta didik mengenal dirinya melalui budaya berbahasa yang telah diturunkan oleh leluhur bangsa Indonesia. Dengan demikian 
perangkat pembelajaran bahasa Indonesia ini bukan semata-mata dipergunakan hanya untuk keperluan guru selama melaksanakan tugasnya, namun perangkat ini juga dapat dijadikan sebagai catatan sejarah (history) yang menggambarkan perkembangan bangsa Indonesia melalui sistem pendidikan khususnya dalam bidang keilmuan bahasa. Jadi baik secara lisan maupun tulisan tidaklah mungkin keilmuan seseorang dalam berbahasa Indonesia dapat diturunkan jika tanpa sistem pembelajaran yang relevan. Oleh sebab itu, perangkat pembelajaran diharapkan menjadi salah satu prioritas yang harus diketahui dan dikuasai oleh guru dalam melakukan pembelajaran.

Berdasarkan uraian di atas, maka dapat diyakini bahwa perangkat pembelajaran bahasa Indonesia memiliki kapabilitas sebagai komponen yang tidak terlepas dalam menyokong kinerja guru. Perangkat ini juga perlu dioptimalkan agar aktivitas belajar siswa dan prestasi belajar siswa dapat tercapai sesuai dengan tujuan pembelajaran dan pendidikan. Dengan demikian, untuk mengetahui keberadaan dan kontribusi perangkat

pembelajaran ini, maka penelitian ini memusatkan variabelnya melalui judul "Eksistensi Perangkat Pembelajaran dalam Meningkatkan Aktivitas dan Prestasi Belajar Siswa VIII di SMP Daya Cipta Medan”

\section{B. KAJIAN TEORI}

\section{Perangkat Pembelajaran}

Perangkat pembelajaran merupukan hal yang harus disiapkan oleh guru sebelum melaksanakan pembelajaran. Dalam KBBI (2007: 17), perangkat adalah alat atau perlengkapan, sedangkan pembelajaran adalah proses atau cara menjadikan orang belajar. Menurut Zuhdan, dkk (2011: 16) perangkat pembelajaran adalah alat atau perlengkapan untuk melaksanakan proses yang memungkinkan pendidik dan peserta didik melakukan kegiatan pembelajaran. Perangkat pembelajaran menjadi pegangan bagi guru dalam melaksanakan pembelajaran baik di kelas, laboratorium atau di luar kelas. Dalam Permendikbud No. 65 Tahun 2013 tentang Standar Proses Pendidikan Dasar dan Menengah disebutkan bahwa penyusunan perangkat pembelajaran merupakan bagian dari perencanaan pembelajaran.

Setiap guru pada satuan pendidikan berkewajiban menyusun perangkat pembelajaran yang berlangsung secara interaktif, inspiratif, menyenangkan, memotivasi siswa untuk berpatisipasi aktif (Poppy Kamalia Devi, dkk, 2009: 1-5). Perangkat pembelajaran yang diperlukan dalam mengelola proses belajar mengajar dapat berupa: silabus, Rencana 
Pelaksanaan Pembelajaran (RPP). Belajar merupakan salah satu kegiatan untuk mengasah dan mengukur kemampuan seseorang dalam mengingat atau menerima materi dan proses pembelajaran yang telahditerima oleh anak, sebab itu sangat dibutuhkan eksistensi yang mendukung anak agar mampu mengembangkan kemampuan dalam belajarnya. Dengan itu juga dibutuhkan peran guru dan orang tua untuk membimbing anak agar mampu mencapai kriteria serta ke objektifanya dalam belajar.

\section{METODE PENELITIAN}

\subsection{Lokasi dan WaktuPenelitian}

Lokasi penelitian ini di SMP Daya Cipta kota Medan. Adapun alamatnya berada di jalan Mistar No. 17 B Sei Putih Bar. Kec. Medan Medan Petisah. Adapun waktu penelitian dilaksanakan selama tiga bulan yaitu maret 2020 - mei 2020.

\subsection{Populasi dan Sampel Penelitian}

Populasi penelitian ini mencakup siswa SMP Daya Cipta Medan. Jumlah kelas keseluruhan 9 kelas dengan tiga kelas parallel pada masing-masing tingkatan. Sampel penelitian ini akan dilakukan pada kelas VIII-B

\subsection{Variabel Penelitian}

Variabel dalam penelitian ini adalah perangkat pembelajaran, prestasi belajar siswa, dan aktivitas belajar siswa. Perangkat pembelajaran mencakup seluruh RPP, media pembelajaran, sarana dan prasarana kelas serta fasilitas ruang kelas lainnya. Prestasi belajar siswa mencakup pelajaran bahasa Indonsia yang memfokuskan pada materi pelajaran yang sedang berjalan. Demikian pada aktivitas belajar siswa juga akan diamaiti selama pembelajaran di dalam kelas.

\subsection{Jenis dan Desain Penelitian}

Jenis penelitian ini adalah deskriptif kualitatif dengan mengutamakan hasil pemaknaan secara subjektif. Menurut Sugiyono (2011: 15) menyatakan bahwa "metode penelitian kualitatif adalah metode penelitian yang berlandaskan pada filsafat postpositivisme, digunakan untuk meneliti pada kondisi objek yang alamiah, dimana peneliti adalah instrument kunci”. Desain penelitian ini akan memusatkan pada pendekatan rancangan penelitian yang dikembangkan dan lingkungan yang alamiah (Creswell, 2010: 225). Artinya pemerolehan data akan didasarkan oleh instrument yang dikembangkan oleh peneliti dan lingkungan alamiah sekolah yang diteliti.

\subsection{Prosedur Penelitian}

Untuk melaksanakan penelitian ini, ditempuh langkah-langkah sebagai berikut : 
1. Tahapan persiapan

Kegiatan yang dilakukan dalam tahap ini meliputi persiapan-persiapan sehubungan dengan pelaksanaan penelitian.

- Konsultasi dengan kepala sekolah untuk memohon izin melakukanpenelitian.

- Menyusun rencana pembelajaran sebagai panduan penelitian dalam proses pencapaian tujuan yang diinginkan.

- Menyusun instrumen untuk memperoleh data tentang hasil belajar siswa.

- Menentukan kelas sampel dari populasi yangada.

2. Tahap pelaksanaan

- Melaksanakan penelitian sesuai dengan road map yang telah disusun.

- Mengikuti dan mengamati proses pembelajaran yang dilakukan guru.

- Melakukan pencatatan dan perekaman proses pembelajaran yang dilakukan oleh guru

- Memberikan tes setelah seluruh pembelajaran telah diajarkan oleh guru

3. Tahapan pengumpulan data

Data dalam penelitian ini dapat dikumpulkan setelah tes diberikan pada siswa, kemudian dilakukan penskoran. Berikut tahapan pengelola datanya :

- Mentabulasikan data yang berhubungan dengan instrument yang diberikan.

- Menggambarkan hasil pengumpulan data berdasarkan instrument yang digunakan dalam penelitian.

- Menganalisis data hasil penelitian bersama dengan pembimbing diseminasi.

\subsection{Alat dan PengumpulanData}

Sebagai alat pengumpulan data dalam penelitian ini digunakan beberapa instrument yaitu: angket, observasi, wawancara dan tes pilihan ganda. Angket merupakan pengumpulan data dengan cara mengajukan pertanyaan atau pernyataan tertulis untuk dijawab oleh responden agar mendapatkan jawaban atau tanggapan dan informasi yang diteliti (Mardalis, 2008:66). Observasi juga akan diterapkan dalam penelitian ini melalui catatan, rekaman dan dokumentasi lainnya. Sehingga angket dan observasi akan disesuaikan terhadap variabel yang diteliti. Selanjutnya untuk wawancara akan dilakukan secara terstruktur yaitu pertanyaan sudah dirancang dan hasilnya akan direkam oleh peneliti. Peneliti juga akan memberikan tes dalam bentuk pilihan ganda, dan soalnya disusun peneliti bersama dengan guru di sekolah tersebut. Jadi dengan demikian varibel prestasi belajar dan aktivitas belajar siswa akan dianalisis bersamaan dengan perangkat pembelajaran melalui instrument di atas. 


\subsection{Teknik Analisis}

Teknik analitis data yang digunakan adalah teknik analisis deskriptif kualitatif. Penelitian kualitatif merupakan penelitian yang digunakan untuk memperoleh data hasil penelitian dari data primer dan sekunder, artinya penelitian akan menemukan, mereduksi dan menyimpulkan komponen-komponen yang memiliki keterkaitan untuk mencapai tujuan penelitian ini. Teknik ini akan menggambarkan data-data hasil penelitian berdasarkan instrument yang telah ditentukan. Selanjutnya data hasil penelitian akan diolah sesuai instrument penelitian.

Berdasarkan instrument yang telah ditentukan maka angket akan dianalisis dengan memedomani kriteria berikut ini:

\begin{tabular}{|l|l|l|}
\hline Kriteria & Positif & Negatif \\
\hline Sangat Setuju & 5 & 1 \\
\hline Setuju & 4 & 2 \\
\hline Ragu-ragu & 3 & 3 \\
\hline Tidak Setuju & 2 & 4 \\
\hline Sangat Tidak Setuju & 1 & 5 \\
\hline
\end{tabular}

Selanjutnya untuk wawancara yang dilakukan peneliti akan memberikan beberapa pertanyaan kepada guru,yang nantinya akan dilakukan penelitian dan observasi yang akan disesuaikan dengan kriteria variabel penelitian seperti, penggunaan RPP, penggunaan media pembelajaran, hasil belajar siswa dalam beberapa tahun yang lewat, fasilitas belajar, serta aktivitas siswa selama disekolah. Sehingga butir wawancara dan observasi akan terpenuhi setelah peneliti melakukan telaah bersama dengan guru dan dosen pembimbing.

Peneliti juga akan membuat tes pilihan ganda dengan menyusun kisi-kisi terlebih dahulu, yaitu kesesuaian materi yang sedang diajar guru, tingkat kesukaran soal, hingga kevalidan soal. Jadi peneliti akan berkonsultasi dengan dosen ahli pendidikan bahasa dan sastra Indonesia. Dan soal yang telah direvisi akan digunakan dalam pengambilan data. Dengan demikian penelitian ini akan lebih mengutamakan hasil setiap instrument terlebuh dahulu, untuk selanjutnya peneliti akan menganalisisnya berdasarkan teknik analisis kualitatif. 


\section{HASIL DAN PEMBAHASAN PENELITIAN}

\subsection{Hasil Penelitian}

\section{A. Deskripsi Instrumen Penelitian}

Berdasarkan metode penelitian yang telah disusun maka data yang perlu dideskripsikan pertama sekali pada bab ini adalah tentang kevalidan instrument penelitian. Seperti angket penelitian ini menggunakan pertanyaan tertulis yang dijawab secara tertulis oleh sampel penelitian. Kemudian soal/ tes objektif dengan menggunakan pertanyaan dengan 4 pilihan jawaban yang dipilih pada lembar jawaban (google form). Kedua instrumen penelitian ini sudah ditelaah oleh para ahli yaitu Bapak Syahrizal Akbar, S.Pd., M.Pd. yang merupakan salah satu dosen pada Prodi Bahasa Indonesia Unpri Medan. Hasilnya diketahui bahwa kedua instrumen tes dan angket dalam penelitian ini layak digunakan untuk mengumpulkan data penelitian. Sedangkan instrumen observasi penelitian disesuaikan dengan identifikasi masalah dan tujuan penelitian ini. Oleh karena itu, peneliti menyusun observasi penelitian dengan indikator yang dapat diinderawi secara langsung.

Dengan demikian seluruh butir indikator instrumen akan dideskripsikan sesuai dengan kebutuhan analisis data dan tujuan penelitian. Selanjutnya data penelitian secara berturut-turut akan dijelaskan mulai dari subjek penelitian, hasil tes dan angket hingga hasil observasi penelitian.

\section{B. Deskripsi Subjek Penelitian}

Sampel penelitian ini adalah SMP Daya Cipta Medan dengan subjek penelitian yaitu kondisi sekolah. Berdasarkan observasi selama melaksanakan penelitian maka dapat dideskripsikan antara lain.

Tabel 3.1. Kondisi SMP Daya Cipta Medan

\begin{tabular}{|l|l|l|}
\hline No & \multicolumn{1}{|c|}{ Kriteria } & Keterangan \\
\hline 1. & Ruang Guru & Baik \\
\hline 2. & Ruang Belajar & Baik \\
\hline 3. & Ruang Kepala Sekolah & Baik \\
\hline 4. & Ruang Perpustakaan & Cukup \\
\hline 5. & Lapangan Sekolah & Baik \\
\hline 6. & Jumlah Siswa & 25 \\
\hline 7. & Jumlah Guru & 12 \\
\hline
\end{tabular}




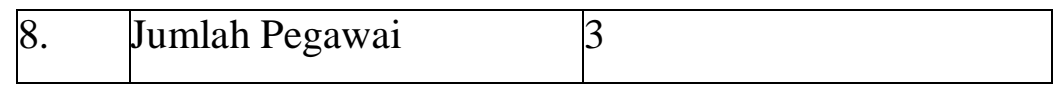

Tabel di atas digunakan untuk mendeskripsikan kondisi sekolah sebagai pendukung analisis data yang terkait dengan tujuan penelitian ini, terutama pada analisis data instrumen observasi yang digunakan. Oleh sebab itu, berdasarkan data tabel ini diketahui bahwa kondisi sekolah ini termasuk kategori baik. Demikian juga perbandingan tenaga kerjanya juga sebanding dengan jumlah siswa dan ruangan yang dikelola oleh sekolah, sehingga aktivitas belajar dan mengajar sekaligus operasional sekolah dilaksanakan secara optimal.

\section{Deskripsi Perangkat Pembelajaran}

Perangkat pembelajaran digunakan dalam penelitian ini berupa Rencana Pelaksaan Pembelajaran (RPP), buku materi, dan alat pendukung pembelajaran lainnya yang digunakan sebagai acuan dalam proses pembelajaran di kelas. Sesuai dengan road map penelitian bahwa garis besar penelitian ini akan memperhatikan pengadaan RPP yang sesuai dengan standar kurikulum yang berlaku, dan penelitian ini juga mendeskripsikan penggunaan media pembelajaran (termasuk buku pelajaran dan sejenisnya) melalui pengamatan dan wawancara dengan guru Bersama pihak sekolah. Hasil penelitian menunjukkan bahwa RPP pelajaran Bahasa Indonesia yang digunakan telah mengacu pada standar kurikulum 2013 revisi 2017. Guru sudah menyusun setiap materi ajar beserta aktivitas belajar dalam RPP secara komprehensif dan terintegrasi. Namun, di masa pandemic covid-19 aktivitas belajar dirancang kembali dengan memanfaatkan laman website seperti gmail, yahoo, google dan juga menggunakan aplikasi berbasis social media internet seperti whatsapp, facebook.

\section{Deskripsi Hasil Tes}

Instrumen tes yang digunakan dalam penelitian ini bertujuan untuk mengetahui prestasi belajar siswa terhadap materi yang diajarkan oleh guru. Terkait materi ajar yang diuji dalam penelitian ini, maka guru sudah menjelaskannya sesuai dengan RPP yang disusun berdasarkan kurikulum yang berlaku. Bahan ajar yang diberikan juga relevan dengan isi pertannyaan tes sehingga pertanyaan butir soal hanya berisi materi yang pernah dijelaskan oleh guru. Peneliti telah menyusun 20 butir soal pilihan ganda dan hasilnya diperoleh sebagai berikut. 
Gambar 3.1. Hasil Tes Pilihan Ganda

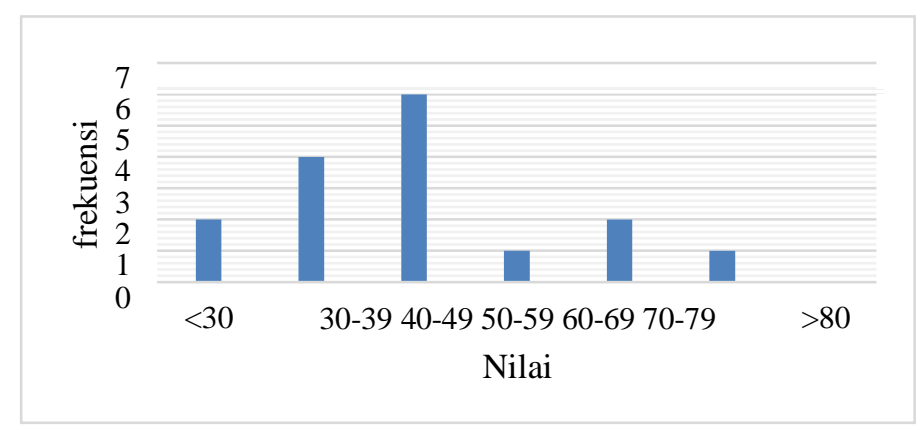

Berdasarkan hasil tes, dapat diketahui bahwa 50\% siswa nilainya di bawah 50 dan nilai tertinggi hanya dapat dicapai oleh 5\% siswa atau satu orang saja dari kelas tersebut. Hasil ini juga menunjukkan bahwa hasil belajar kelas ini masih rendah, mengingat Kriteria Ketuntasan Minimal (KKM) Bahasa Indonesia yang digunakan oleh guru adalah 70. Jadi berdasarkan data tes ini dapat diketahui bahwa terdapat 19 siswa yang tidak mencapai KKM, dan hanya 1 siswa saja yang mencapainya.

\section{E. Deskripsi Hasil Angket}

Penyusunan angket dijabarkan melalui beberapa indikator kemudian dirincikan menjadi butir-butir pertanyaan. Angket ini terdiri dari 20 butir pertanyaan dengan 5 pilihan jawaban ordinal (sangat setuju, setuju, ragu- ragu, tidak setuju, dan sangat tidak setuju). Berikut hasil angket yang telah diteliti. 


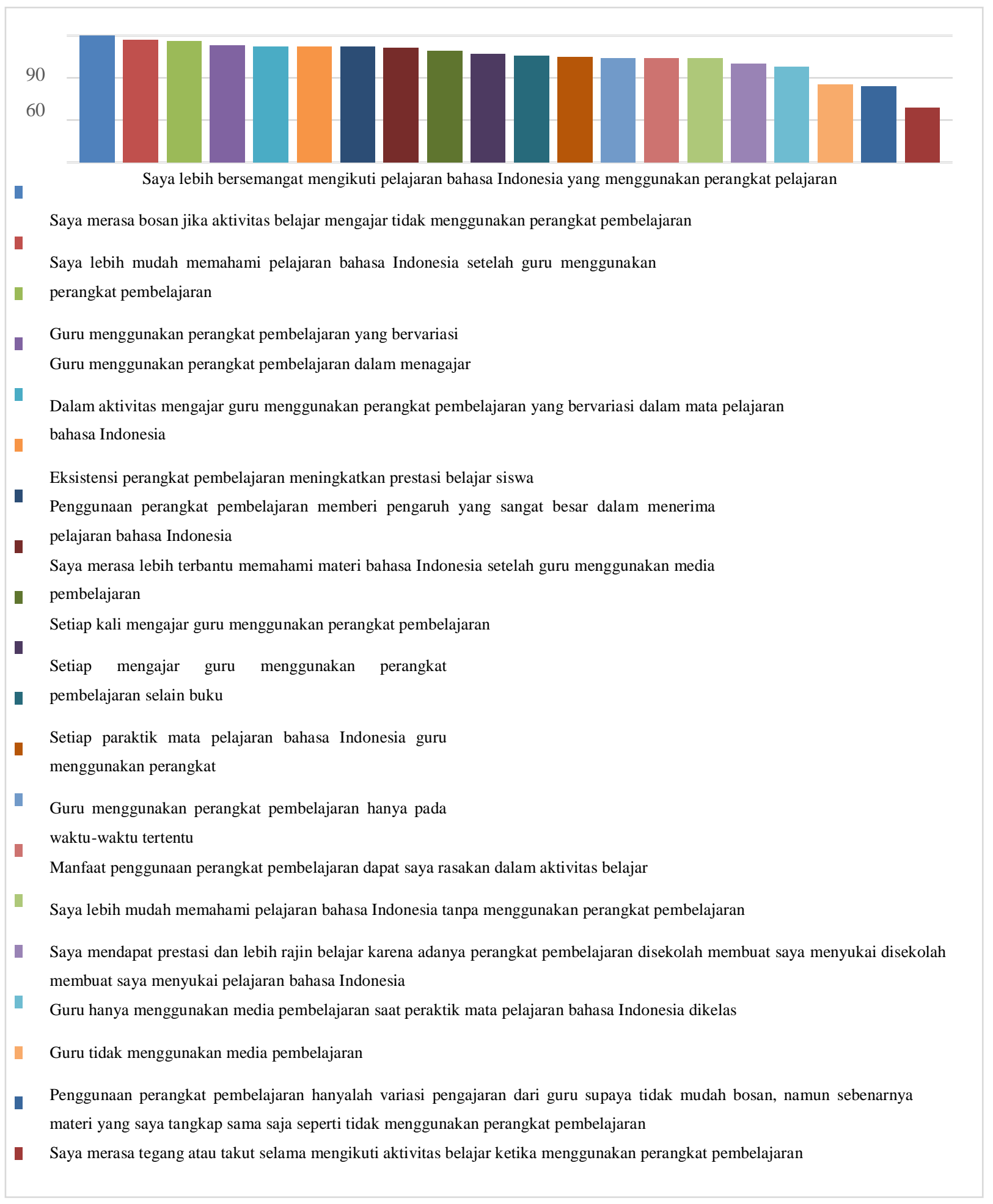

Gambar 3.2. Hasil Angket

Berdasarkan gambar di atas dapat diketahui bahwa sebesar 90\% siswa lebih bersemangat mengikuti pelajaran Bahasa Indonesia yang menggunakan perangkat pembelajaran. Hal ini menunjukkan bahwa aktivitas belajar siswa akan semakin kondusif jika guru mengajar sesuai dengan RPP (perangkat pembejaran). Hasil angket juga 
menunjukkan bahwa hanya 39\% siswa yang merasa tegang dan takut selama mengikuti aktivitas belajar yang diselenggarakan oleh guru. Selebihnya dari 20 indikator angket terdapat 2 kriteria lainnya yang persentasenya kurang dari 50\% dan 17 kriteria lainnya lebih dari $60 \%$ (data terlampir). Jadi dengan demikian dapat diketahui bahwa aktivitas belajar siswa semakin optimal dengan adanya pengajaran yang disusun dalam perangkat pembelajaran. Dan untuk mempertegas hasil angket di atas dapat diketahui bahwa nilai angket yang diberikan kelas ini terhadap penggunaan perangkat pembelajaran dalam pengajaran yaitu 74,4 dan berikut persentase pilihan siswa

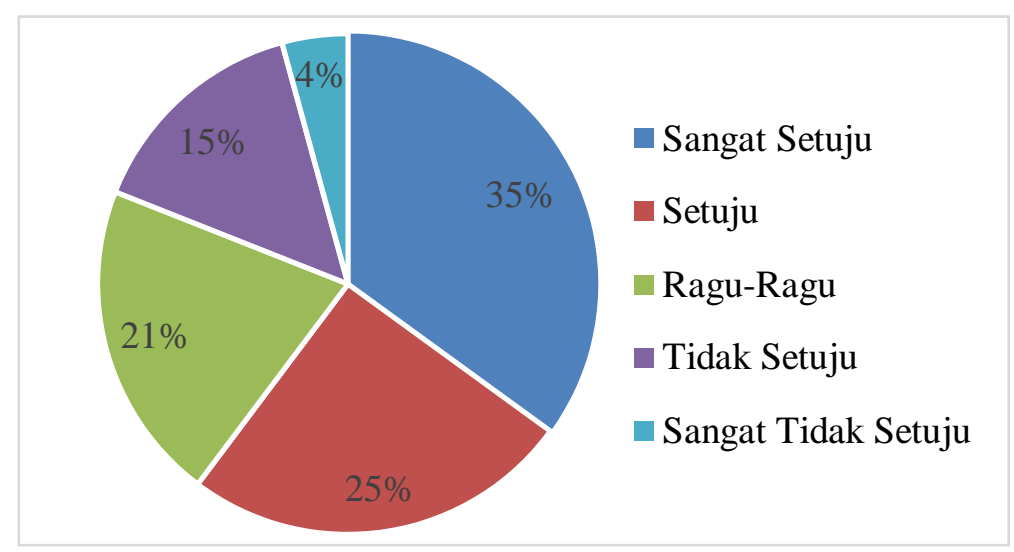

Gambar 3.3. Persentase Pilihan Angket

\section{F. Deskripsi Hasil Observasi}

Pelaksanaan observasi yang telah dilakukan selama 3 bulan bersamaan dengan instrumen penelitian lainnya. Adapun observasi penelitian ini dilakukan untuk menjaga objektivitas penilaian terhadap sekolah dan integrasi tujuan penelitian, selanjutnya berikut ini hasil observasi yang telah diperoleh.

Tabel 3.2. Hasil Observasi Penelitian

\begin{tabular}{|l|c|c|c|c|}
\hline \multirow{2}{*}{ Indikator } & \multicolumn{2}{c|}{ Jumlah Teramati } & \multicolumn{2}{c|}{ Persen Pengamatan } \\
\cline { 2 - 5 } & Tampak & Tidak tampak & Tampak & Tidak tampak \\
\hline $\begin{array}{l}\text { Siswa tidak bersemangat dalam } \\
\text { mengerjakan tugas }\end{array}$ & 5 & 15 & $25 \%$ & $75 \%$ \\
\hline $\begin{array}{l}\text { Siswa pasif, tidak berinteraksi dan tidak } \\
\text { inisiatif mengenai masalah yang diteliti }\end{array}$ & 10 & 10 & $50 \%$ & $50 \%$ \\
\hline $\begin{array}{l}\text { Banyak lomba atau kreativitas yang } \\
\text { terselenggara dan diikuti oleh siswa }\end{array}$ & 12 & 8 & $60 \%$ & $40 \%$ \\
\hline $\begin{array}{l}\text { Siswa bersemangat mengerjakan tes dan } \\
\text { seluruh aktivitas belajar }\end{array}$ & 18 & 2 & $90 \%$ & $10 \%$ \\
\hline
\end{tabular}




\begin{tabular}{|l|l|l|l|l|}
\hline Siswa aktif selama kegiatan penelitian & 15 & 5 & $75 \%$ & $25 \%$ \\
\hline
\end{tabular}

Berdasarkan tabel di atas dapat diketahui bahwa sebesar 90\% siswa tampak semangat mengerjakan tes dan setiap aktivitas belajar yang disusun oleh guru. Namun pada interaksi belajar dan keinisiatifan mengenai masalah penelitian ini tampak 50\% siswa tidak menunjukkan perilaku yang sesuai dengan tujuan penelitian. Ditambah lagi sekitar $60 \%$ siswa yang pernah mengikuti lomba atau kreativitas sekolah/ antar pelajar. Jadi berdasarkan data ini dapat diketahui bahwa aktivitas belajar siswa dan prestasi belajar siswa masing-masing masih menunjukkan adanya ketidakseimbangan walaupun guru sudah mengoptimalkan fungsi perangkat pembelajaran dalam pengajarannya.

\subsection{Pembahasan}

Sesuai dengan deskripsi hasil penelitian yang telah dijelaskan maka dapat diyakini bahwa instrumen yang digunakan sudah memenuhi kriteria kelayakan. Melalui uji kelayakan (data terlampir) yang dilakukan oleh para ahli maka setiap instrumen penelitian ini telah mampu mengukur hasil belajar (prestasi) dan aktivitas belajar siswa melalui eksistensi perangkat pembelajaran. Perangkat pembelajaran yang disusun oleh guru juga menunjukkan efek yang berbeda terhadap instrumen yang digunakan dalam penelitian ini. Hal tersebut terlihat jelas dengan berbedanya hasil tes, angket dan observasi yang diperoleh melalui analisis data penelitian ini.

Pertama, pada hasil tes dapat diketahui bahwa terdapat 95\% siswa yang nilainya berada di bawah KKM dan hanya 5\% siswa yang nilainya mencapai KKM. Padahal substansi materi pertanyaan tes yang diberikan oleh guru sudah dijelaskan secara keseluruhan, bahkan di setiap pertemuan guru selalu memberikan pembelajaran sesuai dengan RPP sekolah. Guru juga sudah memasukkan beberapa pertanyaan yang pernah diberikan ketika pembelajaran normal berlangsung. Pemanfaatan media pembelajaran juga sudah optimal dilakukan oleh guru, seperti penggunaan infocus dan sumber belajar video yang ditayangkan melalui tautan kiriman guru. Namun, tampaknya hasil belajar (prestasi) siswa tidak serta merta dapat meningkat dengan adanya perangkat pembelajaran sekolah.

Berdasarkan temuan ini, peneliti dapat menyakini bahwa siswa di SMP Daya Cipta ini memiliki faktor lain yang dapat meningkatkan hasil belajarnya. Peneliti berasumsi bahwa perangkat pembelajaran ini tidak seutuhnya berkaitan langsung dengan kepentingan mengajar di kelas. Tingkat pemahaman siswa yang beragam, kondisi/ situasi belajar yang berbeda dengan indikator yang dijelaskan pada RPP, dan rendahnya ketertarikan siswa terhadap pelajaran Bahasa Indonesia dianggap sebagai faktor yang menyebabkan rendahnya hasil 
belajar siswa. Oleh karena itu, dalam kasus ini sebaiknya perangkat pembelajaran harus disusun setelah guru memiliki pengetahuan yang kuat/ jelas tentang kondisi kelas dan guru juga harus memiliki keterampilan dalam mendiagnosa kemampuan serta hasrat belajar siswa.

Kedua, hasil angket penelitian telah menunjukkan bahwa dari 20 butir pernyataan terdapat 17 indikator pernyataan yang mencapai lebih dari $60 \%$ hasil yang mengarah ke pilihan positif (setuju). Artinya dari sudut pandang siswa, pengajaran yang diberikan oleh guru telah sesuai dengan harapan siswa selama pembelajaran berlangsung. Penggunaan perangkat pembelajaran (seperti RPP dan media pembelajaran) yang dirasakan siswa cukup mempengaruhi aktivitas belajarnya selama guru mengajar. Siswa juga semakin tahu target pembelajaran dan memahami pola belajar yang dituntut oleh guru secara komprehensif. Tentu hasil ini bertolak belakang dengan hasil belajar siswa yang telah dianalisis sebelumnya. Seharusnya jika penilaian siswa terhadap pengajaran yang dilakukan guru sudah sesuai dengan harapan mereka maka hasil belajarnyapun juga harus meningkat atau mencapai KKM. Oleh sebab itu, berdasarkan kedua hasil instrumen ini tampaknya aktivitas belajar dan prestasi belajar siswa tidak serta merta berkaitan langsung terhadap keberadaan perangkat pembelajaran.

Berdasarkan temuan ini, maka perangkat pembelajaran diasumsikan hanya akan berdampak positif terhadap aktivitas belajar saja dan keberadaannya harus dibarengi dengan faktor lainnya untuk meningkatkan hasil belajar (prestasi) siswa. Peneliti juga melihat adanya pandemic covid-19 memberikan dampak negatif terhadap proses pembelajaran yang telah disusun guru dalam RPP. Siswa menjadi kurang termotivasi untuk belajar akibat sistem pembelajaran jarak jauh (daring dan luring). Walaupun siswa diijinkan datang ke sekolah untuk belajar langsung dengan guru tetapi tetap saja siswa lebih memilih belajar di rumah demi menjaga kesehatan di masa pandemic ini. Jadi kemungkinan besar rendahnya nilai siswa dalam penelitian ini disebabkan oleh adanya perubahan sistem belajar, dari pembelajaran tatap muka menjadi pembelajaran jarak jauh.

Ketiga, hasil observasi penelitian ini menunjukkan adanya semangat dalam mengerjakan tes dan antusiasme mengikuti pembelajaran secara langsung di kelas. Sebagaimana telah dideskripsikan pada hasil penelitian bahwa persentasenya mencapai $90 \%$. Data ini tampaknya tidak linier dengan hasil tes, tetapi peneliti yakin bahwa siswa memiliki hasrat untuk mengerjakan tes meskipun pengetahuan siswa tentang materi yang telah dijelaskan cenderung belum tuntas. Hasil observasi juga menunjukkan bahwa terdapat $60 \%$ siswa pernah mengikuti lomba atau kreativitas sekolah, sehingga adanya perangkat pembelajaran ini tampaknya lebih optimal untuk mengembangkan aktivitas belajar siswa dan 
meningkatkan keterampilan siswa secara afektif.

Berdasarkan temuan ini, peneliti berasumsi bahwa sebagian besar hasil observasi penelitian mengarah pada dampak pengiring lainnya yakni perangkat pembelajaran membuat siswa mampu mengembangkan bakat dan minat lainnya. Penelitian ini juga menunjukkan bahwa hasil belajar (prestasi) siswa harus dieksplorasi dengan berbagai cara dan bukan hanya melalui pengembangan RPP atau media pembelajaran saja. Guru juga harus mampu menerapkan dan mengimprovisasi penggunaan perangkat pembelajaran yang terintegritas dengan komponen pembelajaran lainnya. Jadi, variabel penelitian yang teramati ini memberikan kontribusi dalam profesi guru Bahasa Indonesia, khususnya dalam mengoptimalkan fungsi dan tujuannya sebagai salah satu alat interaksi yang strategis pada setiap disiplin ilmu lainnya.

Dengan terhimpunnya uraian di atas, maka penelitian ini telah menunjukkan bahwa aktivitas belajar dan prestasi belajar dapat ditingkatkan melalui perangkat pembelajaran. Hanya saja pada variabel prestasi belajar, keberadaan perangkat pembelajaran perlu diuji dan ditelaah secara serius oleh penggunanya. Karena prestasi belajar sangat berkaitan dengan kemampuan berpikir (aspek kognitif), sehingga guru perlu mendiagnosis kemampuan siswa terlebih dahulu sebelum melakukan pembelajaran yang dirancang dalam RPP. Sedangkan variabel aktivitas belajar siswa, telah menunjukkan hasil yang signifikan. Hasil angket dan observasi secara keseluruhan memberikan kontribusi pada peningkatan afektif dan psikomotorik siswa saja. Aktivitas belajar siswa menjadi teratur dan terarah serta keterampilan siswa lebih berkembang sesuai dengan hasrat belajar mereka. Hal ini tampak dengan adanya lomba atau kreativitas yang diikuti oleh siswa secara rutin melalui bimbingan guru di sekolah.

Selanjutnya sesuai dengan road map penelitian ini bahwa pelaksanaan pembelajaran sebelum dan setelah mengoptimalkan penggunaan perangkat pembelajaran maka akan dianalisis eksistensinya terhadap prestasi belajar dan aktivitas belajar siswa. Dan hasilnya diketahui bahwa hasil belajar siswa sebelum dan sesudahnya tidak mengalami peningkatan sama sekali, bahkan ada beberapa siswa nilainya menurun setelah dioptimalkannya pengguanan perangkat pembelajaran. Sebagaimana telah dijelaskan sebelumnya bahwa hal ini dapat terjadi akibat sistem belajar yang berubah, ditambah lagi kemampuan siswa yang beragam. Sedangkan aktivitas belajar siswa tampaknya mengalami peningkatan yang cukup signifikan, karena dengan adanya optimalisasi penggunaan perangkat pembelajaran siswa semakin mengetahui kaarakter belajarnya dan hasrat belajar yang dimiliki. Artinya, siswa semakin memahami potensi yang dimilikinya melalui aktivitas yang dieksplorasi melalui 
perangkat pengajaran yang disusun oleh guru.

\section{E. KESIMPULAN}

Berdasarkan dari hasil penelitian yang dilakukan dapat disimpulkan. Terdapat kesulitan dimana siswa kurang mampu menguasai beberapa bagian materi pembelajaran bahasa Indonesia, maka dari itu untuk meningkatkan eksistensi belajar siswa dalam metode belajar diperlukan RPP, buku materi dan alat pendukung sebagai acuan dalam proses alat bantu pembelajaran dikelas ataupun diluar kelas.Hasil Penelitian ini menunjukkan bahwa RPP pelajaran bahasa Indonesia yang digunakan sudah mengarah pada standar kurikulum 2013 revisi 2017, guru juga sudah menyusun RPP setiap mata pelajaran beserta aktivitas belajar dalam RPP secara komperehensif. Sesuai dengan keadaan pandemic covid-19 dimana aktivitas belajar siswa dirancang dengan menggunakan dan memanfaatkan website seperti gmail, yahoo, google dan sosial media internet seperti whatsapp dan facebook.Tujuan penelitian ini dilakukan agar megetahui presentasi belajar siswa terhadap materi yang diajarkan guru mata pelajaran terutama pelajaran bahasa Indonesia.

\section{F. SARAN}

Berdasarkan dari hasil penelitian yang dilakukan di sekolah SMP Daya cipta ada beberapa masukan terhadap siswa untuk meningkatkan kemampuan belajar, terutama pada materibahasa Indonesia :

1. Siswa harus mampu mengulang dan menguasai materi pembelajaran bahasa Indonesia.

2. Siswa diwajibkan bertanya apabila materi yang di ajarkan kurang dimengerti ataupun tertinggal materi pembelajaran.

3. Guru memberikan tugas sekolah sebagai bahan evaluasi dirumah.

4. Sangat diperlukan motivasi, dorongan dari orang tua dan guru.

5. Membuat kelompok diskusi kecil untuk mengulas materi pembelajar.

\section{DAFTAR PUSTAKA}

Arikunto, Suharsimi. 2006. Prosedur Penelitian suatu Pendekatan Praktik, Jakarta: PT Rineka Cipta

Aqib, Zainal. 2002. Profesionalisme Guru dalam Pembelajaran. Surabaya: InsanCendekia.

Creswell, J.W. 2010. Research design: pendekatan kualitatif, kuantitatif, dan mixed. Yogjakarta: PT Pustaka Pelajar. 
Depdiknas. 2007. Pedoman Pembelajaran Permainan Berhitung Pemulaan Di Taman Kanak- kanak. Jakarta: Dirjen Dikdasdem Indonesia, U. P. , \& UNPRI M. (2019, March). PROSIDING SEMINAR NASIONAL FAKULTAS KEGURUAN DAN ILMU PENDIDIKAN. In SEMINAR NASIONAL UNPRI (Vol.1, No.1).

Mardalis. 2008. Metode Penelitian Suatu Pendekatan Proposal. Jakarta: Bumi Aksara.

Mappa, Syamsu. 1984. Teori belajar. Jakarta: Depdikbud.

Moleong, Lexy J. 2007. Metode Penelitian Kualitatif. Bandung: PT Remaja Rosdakarya

Pardede, O. B. 2019. Eksperimentasi Penerapan Analisis SWOT dalam Merumuskan Strategi "Pemasaran" Professional Pendidik melalui Motivasi Kerja. Bahasa Indonesia Prima (BIP), 1(2), 7-14.

Pardede, O. B., \& Ariga, H. P. S. 2018. Analisis Faktor-Faktor Kendala Penulisan Karya Tulis Ilmiah dan Dampaknya terhadap Motivasi Meneliti oleh Guru di SMP seKecamatan Medan Selayang. In Prosiding Seminar Nasional Pendidikan Bahasa dan Sastra Indonesia I Unimed-2018 (Vol.1, pp. 71-77). FBS Unimed Press.

Sugiyono. 201. Metode Penelitian kualitatif, kuantitatif, dan R\&D. Bandung: ALFABETA.

Sugiyono. 2011. Data kuantitatif adalah data yang berbentuk angka, atau data kualitatif yang diangkakan. Bandung.

Sanjaya, Wina. 2007. Strategi Pembelajaran. Jakarta: Kencana Prenada Media Group

Sugiyono. 2008. Metode Penelitian Pendidikan. Bandung: AlfaBeta.

Usman, Uzer. 1993. Upaya Optimalisasi Kegiatan Belajar Mengajar. PT. Remaja Rosda karya: Bandung

Yamin, Martinis, 2007, Strategi Pembelajaran Berbasis Kompetensi. Jakarta: Gaung Persada Press.

Zuhdan Kun Prasetyo, dkk. 2011. Pengembangan Perangkat Pembelajaran Sains Terpadu untuk Meningkatkan Kognitif, Keterampilan Proses, Kreativitas serta Menerapkan Konsep Ilmiah Peserta Didik SMP. Yogyakarta: Pascasarjana UNY. 